\title{
Investigation of hydropower energy potential and policy shift from natural gas to hydropower energy in Turkey
}

\author{
Türkiye'de hidroelektrik enerji potansiyeli araștırması ve doğal gazdan \\ hidroelektriğe geçiş politikası
}

\author{
Mutlu YASSAR ${ }^{*}$ iD \\ 1Department of Civil Engineering, Faculty of Engineering, Pamukkale University, Denizli, Turkey. \\ mutluyasar@pau.edu.tr
}

Received/Gelis Tarihi: 19.08.2016, Accepted/Kabul Tarihi: 16.10.2017

doi: $10.5505 /$ pajes.2017.71135

* Corresponding author/Yazıșllan Yazar Research Article/Araștırma Makalesi

\begin{abstract}
This study investigates the possible hydropower potential of Turkey, using literature and the General Directorate of State Hydraulic Works plans. Based on the obtained hydraulic potential, two scenarios are proposed. The first scenario is an electricity investment and share of electricity production continuing as a historical trend, while the second scenario is the increase in the share of hydropower plants in total electricity production as 35\%, including a newly calculated potential of 156 TWh. The results show that the hydropower potential of Turkey increased from 140 to 156 TWh with a level of $12 \%$. Scenario I shows that the total share of electricity production from hydropower changed from $25 \%$ to $26 \%$ but natural gas did not change. Scenario II shows that natural gas power production will decrease from $42 \%$ to $30 \%$ and hydropower production increase from $26 \%$ to $35 \%$ in 2023. The results also show that if Scenario II is applied, the cumulative present value of gain will be approximately $32 \%$ in 2043 with a savings of about $\$ 25$ billion.
\end{abstract}

Keywords: Energy policy, Renewable energy sources, Hydropower

\section{Öz}

Bu çalıșmada Türkiye'nin hidroelektrik potansiyeli literatür ve Devlet $\mathrm{Su}$ İsleri planları cerçevesinde araștırılmıștır. Elde edilen hidrolik potansiyele dayanarak iki senaryo olușturulmuștur. Ilk senaryoda mevcut eğilimin sürdürülmesi durumunda elektrik üretimi için gerekli yatırımlar değerlendirilirken, ikinci senaryoda yeni hesaplanan 156 TWh'lik potansiyele sahip olan hidroelektrik santrallerin elektrik üretimindeki payının \%35 olması durumu incelenmiștir. Türkiye'nin hidroelektrik potansiyelinin literatürde belirtilen 140 TWh değerinden \%12 fazla yani 156 TWh olduğu ortaya konulmustur. Senaryo 1'e göre elektrik üretiminde hidrolik kaynakların payı \%25'ten \%26'ya çıkarken doğal gazın payı değismemistir. Senaryo 2'ye göre doğal gazdan üretilen elektriğin payı \%42'den \%30'a düsserken, hidroelektriğin payı $\% 26$ 'dan \%35'e yükselmiștir. Sonuçlar, Senaryo 2'nin Senaryo 1'e göre 2043 yılı için \%32 daha karlı olacağını ve kazancın bugünkü değerinin yaklaşık 25 milyar dolar mertebesinde olacağını göstermiştir

Anahtar kelimeler: Enerji politikası, Yenilenebilir enerji kaynakları Hidroelektrik

the Gross Hydropower Potential (GHP) of Turkey is approximately the same for all studies, but the EFP ranges from 125 to 188 TWh. Most of the studies [5]-[14] indicate that the EFP is approximately 140 TWh. Bakir [7] ascertained that the EFP is 188 TWh by introducing so-called "new criteria" for calculation of the EFP, but this would be unrealistic with the lack of available data.

As previously indicated that the EFP of hydropower in Turkey ranges in terms of estimated values, investigation needs to be conducted in order to find the realistic values of the EFP. As shown in Table 1, the realistic EFP in Turkey would rise to $156 \mathrm{TWh}$ by taking into account the installed and planned hydropower power plants. According to the new values of EFP, there should also be a policy shift from natural-gas power production to hydroelectric power plants within the vision of the 2023 strategy. Similarly, Yüksek [15] also predicted that hydropower can meet $25-35 \%$ of Turkey's electric energy demand in 2020 .

To fill the gap in the literature, this study proposes to reinvestigate the EFP in Turkey and a policy shift from natural gas to hydroelectric power production. This study also makes an economic appraisal of the shift from natural gas investments to hydroelectric power investments in terms of the present value of costs. 
Table 1: Calculated hydropower potential in Turkey by source.

\begin{tabular}{lcccc}
\hline \multicolumn{1}{c}{ Sources } & Gross hydropower potential (TWh) & Installed capacity (MW) & TFP (TWh) & EFP (TWh) \\
\hline Toklu et al. [5] & - & 45,000 & - & 140 \\
Capik et al. [6] & 433 & - & 216 & 140 \\
Bakir [7] & 433 & 55,099 & - & 188 \\
Yuksek and Kaygusuz [8] & 433 & 35,540 & - & 125 \\
Kaygusuz [9] & - & 35,309 & - \\
Yuksek et al. [10] & 435 & 12,600 & 215 \\
DSi[11] & 433 & 36,950 & - & - \\
Berkun [12] & 433 & - & 128 \\
Dursun and Gokcol [13] & 433 & $-38,006$ & 216 \\
Yüksel [14] & - & 45,314 & - & 125 \\
This Study (explained in Section 4) & 433 & & - & 140 \\
\hline
\end{tabular}

This paper has the following form: Section 2 looks at the brief overview of electricity demand of Turkey. Section 3 presents the future energy demand, Section 4 is an investigation of hydropower potential and Section 5 is a scenario analysis. Financial calculations are given in Section 6, and the last section provides conclusions.

\section{An overview of electricity demand in Turkey}

Energy is of vital importance for humankind. It is well known that electrical energy must be produced when it is to be consumed. Therefore, the essential determinant in electrical energy production is the demand size. Because the part of the installed capacity that can be transformed into energy will only be produced in proportion to the size of the demand, a part of the capacity must be ready for production as reserve without being constantly produced constantly. The power plants in the system are operated based on their disposability, and electricity is generated to meet the demand. Disposability may be easily achieved in the accumulation of hydroelectric power plants and thermal power plants, and it is determined based on the availability of operating conditions.

Turkey occupies a significant land area and has a population in excess of 76 million. With a total domestic income of $\$ 772$ billion and domestic income per capita of $\$ 10,000$, the country has an annual average energy consumption of 3,099 kWh per capita. In comparison, the world average is $2,500 \mathrm{kWh}$, the average of developed countries is $8,900 \mathrm{kWh}$ and the US average is $12,322 \mathrm{kWh}$. Over the past 20 years, when Turkey's peak time demand is higher than the world average, it is also far lower than that of developed countries and the US [16],[17].

Energy needs in Turkey are supplied by various sources. A total of $73 \%$ of the overall energy supply in 2010 was met from imports. For example, $93 \%$ of petroleum, $98 \%$ of natural gas and $90 \%$ of hard coal [18] were imported, making Turkey a net importer of energy. While the majority of the electricity supply was met by hydroelectric power plants and lignite-fired power plants in the early 1980s, most of today's supply is met by natural gas and hydroelectric power plants. This is not an acceptable situation for the country, which lacks a proven natural gas reserve, in terms of the cost and security of the energy supply.

Energy demand in Turkey increased rapidly from 1990 to 2014 by a factor of 4.5 , as can be seen in Table 2 . The installed peak-time power demand increased from approximately 9,000 to $41.000 \mathrm{MW}$. At the same time, the energy demand increased from 56 to $257 \mathrm{TWh} / \mathrm{yr}$ during the years from 1990 to 2014
[15]. The negative increase in 2001 and 2009 shows economic crisis in Turkey that hit two times within the past 15 years.

The demand given in Table 2 is supplied by various sources, as shown in Figure 1 [16]. As can be seen in Figure 1, natural gas reached about 25,600 MW by 2014 and still demonstrates increasing trend. Production based on hydraulic resources has also substantially increased, reaching approximately 23,600 MW. By the year 2014, energy production trends from natural gas and hydroelectric power plants are roughly similar. Additionally, after 2008 energy production from geothermal and wind increased by approximately 3,600 MW.

Table 2: Peak-time power and energy demand in Turkey (TEİAŞ).

\begin{tabular}{ccccc}
\hline Years & $\begin{array}{c}\text { Peak-time } \\
\text { power demand } \\
(\mathrm{MW})\end{array}$ & $\begin{array}{c}\text { Increase } \\
(\%)\end{array}$ & $\begin{array}{c}\text { Energy } \\
\text { demand } \\
\text { (GWh) }\end{array}$ & $\begin{array}{c}\text { Increase } \\
(\%)\end{array}$ \\
\hline 1990 & 9,180 & 7.3 & 56,812 & 8.0 \\
1991 & 9,965 & 8.5 & 60,499 & 6.5 \\
1992 & 11,113 & 11.5 & 67,217 & 11.1 \\
1993 & 11,921 & 7.3 & 73,432 & 9.2 \\
1994 & 12,760 & 7.0 & 77,783 & 5.0 \\
1995 & 14,165 & 11.0 & 85,552 & 10.0 \\
1996 & 15,231 & 7.5 & 94,789 & 10.8 \\
1997 & 16,926 & 11.1 & 105,517 & 11.3 \\
1998 & 17,799 & 5.2 & 114,023 & 8.1 \\
1999 & 18,938 & 6.4 & 118,485 & 3.9 \\
2000 & 19,390 & 2.4 & 128,276 & 8.2 \\
2001 & 19,612 & 1.1 & 126,871 & -1.1 \\
2002 & 21,006 & 7.1 & 132,500 & 4.4 \\
2003 & 21,729 & 3.4 & 141,151 & 6.5 \\
2004 & 23,485 & 8.1 & 150,018 & 6.3 \\
2005 & 25,174 & 7.2 & 160,794 & 7.2 \\
2006 & 27,594 & 9.6 & 174,637 & 8.6 \\
2007 & 29,249 & 6.0 & 190,000 & 8.8 \\
2008 & 30,517 & 4.3 & 198,085 & 4.3 \\
2009 & 29,870 & -2.1 & 194,079 & -2.0 \\
2010 & 33,392 & 11.8 & 210,434 & 8.4 \\
2011 & 36,122 & 8.2 & 230,603 & 9.4 \\
2012 & 39,045 & 8.1 & 242,370 & 5.2 \\
2013 & 38,274 & -2.0 & 248,324 & 2.5 \\
2014 & 41,003 & 7.1 & 257,220 & 3.6 \\
\hline
\end{tabular}

As can be seen in Figure 2, by the year 2014 Turkey met approximately $35 \%$ of its energy need from hydraulic resources, $37 \%$ from natural gas, $22 \%$ from lignite and coal, and $6 \%$ from other resources. In a country that meets a total of $60 \%$ of its need from thermal resources, an increased number of 
hydroelectric power plants will provide environmental and economic benefits.

Figs. 1 and 2 indicate that the energy production from natural and hydroelectric power plants is in increasing trend, but there is a question of how it would be shifted from natural gas to hydropower energy if there is enough potential for hydro. This is discussed in Section 4.

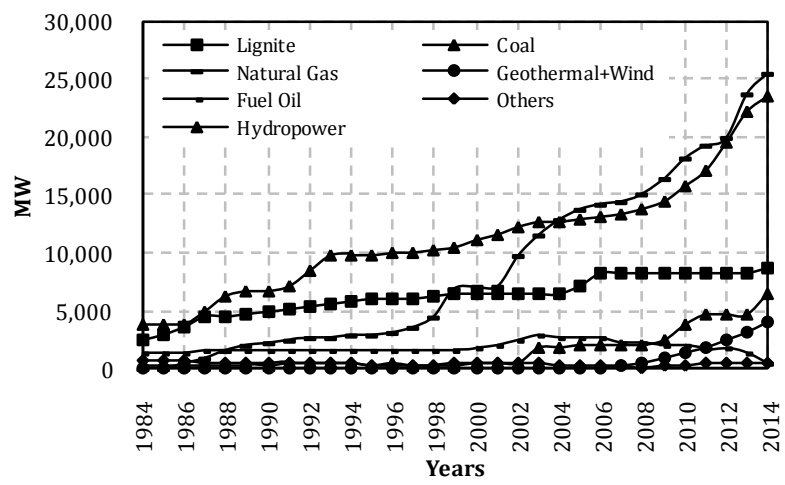

Figure 1: Distribution of energy production in Turkey by source and year (TEİAŞ).

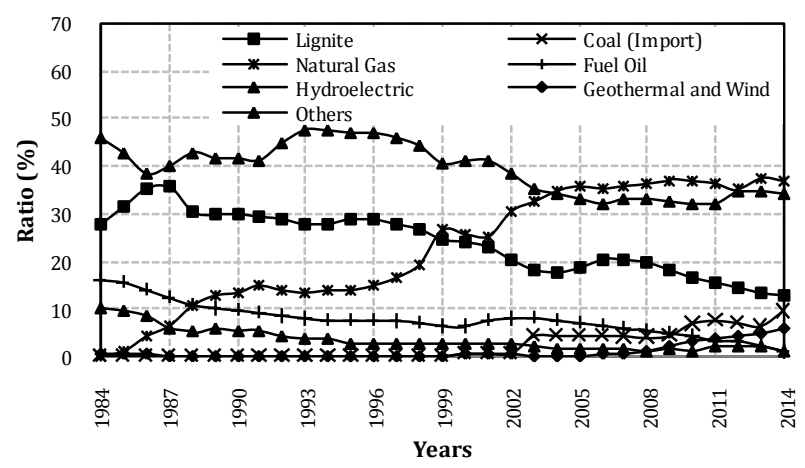

Figure 2: Electrical production in Turkey by source and year (TEİAŞ).

\section{Energy demand projection for Turkey}

Several national and international organizations strive to forecast possible increases in energy demand based on certain assumptions for the coming years. Such forecasts corroborate each other with admissible deviations. In view of the report published by the Turkish Electricity Transmission Company (TEIASS), Turkey's peak demand of 42,375 MW for 2015 will increase to approximately 69,200 MW in high-demand projection or to around $63,759 \mathrm{MW}$ in low-demand projection, as given in Table 3 [16].

TEIAS projects Turkey's electricity demand according to two economic scenarios. The first case is "high demand," for which the average growth rate of the Turkish economy is approximately $7.5 \%$. The second case is "low-demand," for which the average growth rate of the Turkish economy is approximately $6.5 \%$. According to those assumptions, the two cases are given in Table 3. As can be seen in that table, the energy demand in 2023 will rise to about $414 \mathrm{TWh} / \mathrm{yr}$ in the low-demand scenario, which is roughly equivalent to the theoretical capacity of the GHP of Turkey in the low-demand scenario.
Table 3: Projection of energy demand (TEİAŞ).

\begin{tabular}{|c|c|c|c|c|c|}
\hline \multirow[b]{2}{*}{ Years } & & \multicolumn{2}{|c|}{ Peak-Time Demand } & \multicolumn{2}{|c|}{ Energy Demand } \\
\hline & & MW & $\begin{array}{c}\text { Increase } \\
(\%)\end{array}$ & GWh & $\begin{array}{c}\text { Increase } \\
(\%)\end{array}$ \\
\hline 2015 & \multirow{9}{*}{ 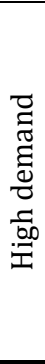 } & 42,375 & 3.3 & 275,140 & 7.0 \\
\hline 2016 & & 45,744 & 7.9 & 297,010 & 7.9 \\
\hline 2017 & & 49,357 & 7.9 & 320,470 & 7.9 \\
\hline 2018 & & 52,454 & 6.3 & 340,580 & 6.3 \\
\hline 2019 & & 55,724 & 6.2 & 361,810 & 6.2 \\
\hline 2020 & & 59,175 & 6.2 & 384,220 & 6.2 \\
\hline 2021 & & 62,363 & 5.4 & 404,920 & 5.4 \\
\hline 2022 & & 65,704 & 5.4 & 426,610 & 5.4 \\
\hline 2023 & & 69,202 & 5.3 & 449,320 & 5.3 \\
\hline 2015 & \multirow{9}{*}{ 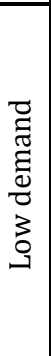 } & 41,402 & 1.0 & 268,820 & 4.5 \\
\hline 2016 & & 43,826 & 5.9 & 284,560 & 5.9 \\
\hline 2017 & & 46,383 & 5.8 & 301,160 & 5.8 \\
\hline 2018 & & 49,043 & 5.7 & 318,430 & 5.7 \\
\hline 2019 & & 51,861 & 5.7 & 336,730 & 5.7 \\
\hline 2020 & & 54,811 & 5.7 & 355,880 & 5.7 \\
\hline 2021 & & 57,689 & 5.3 & 374,570 & 5.3 \\
\hline 2022 & & 60,668 & 5.2 & 393,910 & 5.2 \\
\hline 2023 & & 63,759 & 5.1 & 413,980 & 5.1 \\
\hline
\end{tabular}

\section{Hydropower potential in Turkey}

Turkey has important, valuable hydropower potential, particularly in the introduction of small hydropower plants. Hydropower is the most important renewable, sustainable energy source. There have been several studies on the country's technical and economic hydroelectric potential. The literature given in Table 1 indicates that the theoretical hydroelectric potential is approximately $433 \mathrm{TWh}$, the technically usable potential is $216 \mathrm{TWh}$ and the economic hydroelectric energy potential is $140 \mathrm{TWh} /$ year. However, these studies have proposed that the hydroelectric potential will exceed the calculation because the contributions of Small Hydroelectric power Plants (SHPs) are generally disregarded.

The full utilization of hydropower potential in Turkey is the most important vision in 2023, given that it would be used to decrease the share of imported energy. For that purpose, the private sector has also expressed support for the creation of SHPs in a short term of one to three years. According to a study by Melikoglu [19], Turkey's fresh water reserves have been divided into 25 river basin sand more than $95 \%$ of the country's potential has been distributed into 14 river basins. According to that study, the EFP reached level of 123,040 GWh/yr in 2012. The reason for this increase is the introduction of privatesector construction of SHPs on a build-operate-transfer basis.

In this study, the EFP of hydropower in 2015 is investigated by using the DSİ data to calculate the new hydroelectric potential. The hydropower plants, their installed capacity and energy production are given in Table 4.

Table 4 shows that 20,800 MW installed capacity and 73,639 $\mathrm{GWh} / \mathrm{yr}$ have been under operation. Among this, 55\% is owned by the public and $33 \%$ is owned by the private sector. A summary of the power plants that have been under construction and/or planned by both the state and the private industry is presented in Table 4 according to 2015 values. 
Table 4: Hydropower plants in Turkey (DSí).

\begin{tabular}{|c|c|c|c|c|c|c|}
\hline & & Owning & Quantity & $\begin{array}{c}\text { Installed } \\
\text { capacity } \\
\text { (MW) }\end{array}$ & $\begin{array}{c}\text { Annual } \\
\text { production } \\
\text { (GWh) }\end{array}$ & $\begin{array}{l}\text { Ratio in } \\
\text { production } \\
(\%)\end{array}$ \\
\hline \multirow{14}{*}{ 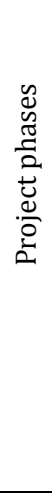 } & & DSİ & 62 & 11,625 & 41,001 & 26.3 \\
\hline & Under & Private sector & 271 & 6,851 & 24,201 & 15.5 \\
\hline & \multirow[t]{2}{*}{ operation } & Other & 76 & 2,324 & 8,437 & 5.4 \\
\hline & & Sum & 409 & 20,800 & 73,639 & 47.2 \\
\hline & \multirow{3}{*}{$\begin{array}{c}\text { Under } \\
\text { construction }\end{array}$} & DSİ & 7 & 2,669 & 8,456 & 5.4 \\
\hline & & Private sector & 186 & 6,866 & 21,908 & 14.0 \\
\hline & & Sum & 193 & 9,535 & 30,364 & 19.4 \\
\hline & \multirow{3}{*}{$\begin{array}{l}\text { Under } \\
\text { planning }\end{array}$} & DSİ & 1 & 290 & 768 & 0.5 \\
\hline & & Private sector & 812 & 14,689 & 51,229 & 32.9 \\
\hline & & Sum & 813 & 14,979 & 51,997 & 33.4 \\
\hline & \multirow{3}{*}{ Total } & DSİ & 70 & 14,584 & 50,225 & 32.2 \\
\hline & & Private sector & 1,269 & 28,406 & 97,338 & 62.4 \\
\hline & & Other & 76 & 2,324 & 8,437 & 5.4 \\
\hline & \multicolumn{2}{|c|}{ Overall Sum } & 1.415 & 45,314 & 156,000 & 100.0 \\
\hline
\end{tabular}

The table shows that the private sector share has increased to a level of 6,866 MW installed capacity and 21,908 GWh, thus increasing its share from $33 \%$ to $72 \%$ as can be seen in Figure 3. Moreover, the planned hydropower by the private sector will be approximately $98 \%$ in the near future [11]. The planning conducted by the TEİAS, which formulates and implements the country's energy policies, is presented in Table 4 [16]. Based on the introduction of the private sector along with public, it is projected that, by using the values in Table 4 , Turkey's EFP will increase from 140 to 156 TWh within the next 10 years (by 2025). Overall, the country's potential technically and economically viable hydroelectric installed capacity is projected to be $45,314 \mathrm{MW}$ with an annual average production of $156 \mathrm{TWh} / \mathrm{yr}$. The potential is observed to increase by (156-140)/140 TWh $=12 \%$. Therefore, the present situation indicates that an additional potential of 24,514 $(9,535+14,979)$ MW has yet to be realized.

The reason for the rapid growth of hydropower energy production is that the introduction of privatization came into the agenda with the enforcement of Law No. 3096 dated 04.12.1984. A share of the public and private sectors in total energy production is given Figure 3.

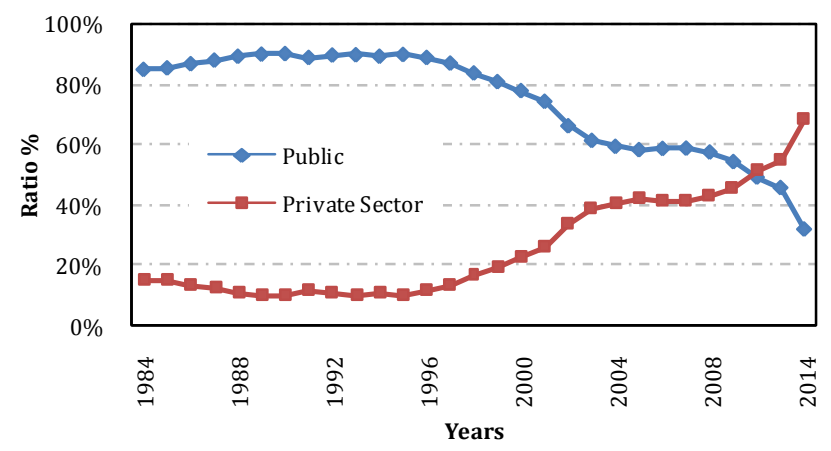

Figure 3: Shares of the public and private sectors in total energy production (EPDK).

Figure 3 shows that the energy production remained stable until 1998. Meanwhile, a quantitative development of the installed capacity and electricity production from 1984 to the end of 2014. The public share of total electricity production in Turkey decreased from $85 \%$ in 1984 to $32 \%$ in 2014 . On the other hand, the private sector's share of the production total increased. Additionally, Figure 4 shows the total shares of natural gas and hydropower electricity production. The share of natural gas was approximately $48 \%$ in 2014 and that of hydropower was approximately $16 \%$. There is still a huge gap in these two sources in terms of electricity production.

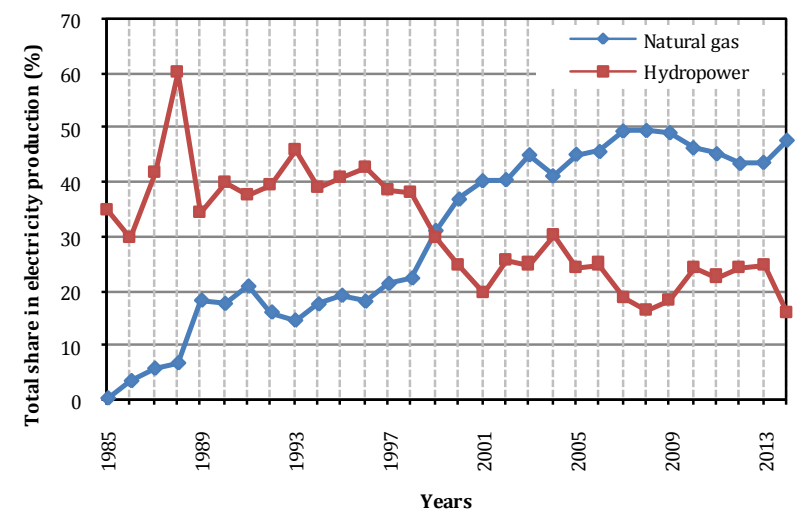

Figure 4: Total share in natural gas and hydropower in total electricity generation (TEİAŞ).

Given this reserve of the hydropower energy production and general trend of private sector investments in energy production, there is a need to re-justify the electrical energy production policy from different sources. Although the TEIASS intends to decrease the total share of natural-gas power production to the level of $35 \%$, this would be investigated since the EFP is higher than the estimated current value. In that regard two scenarios are proposed using historical data and estimated new values of the EFP.

As can be seen in Table 5, that hydroelectric power plants with a total installed capacity of 7,458 MW will be commissioned within the next five years. The TEIAS plans to increase hydraulic resources to approximately $37 \%$ of total production and other resources by approximately $2 \%$ of total production while decreasing shares of natural-gas power plants to approximately $35 \%$ and lignite-fired power plants to approximately $11 \%$ but keeping imported coal resources stable at approximately $8 \%$. 
Table 5: Projection of installed capacities of the public and private sectors under construction based on different power sources.

\begin{tabular}{|c|c|c|c|c|c|c|c|c|}
\hline & \multirow{2}{*}{ Sources } & \multirow{2}{*}{ Unit } & \multicolumn{5}{|c|}{ Years } & \multirow{2}{*}{ Sum of decided } \\
\hline & & & 2015 & 2016 & 2017 & 2018 & 2019 & \\
\hline \multirow{14}{*}{ 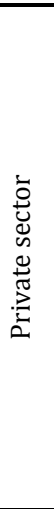 } & \multirow{2}{*}{ Hydroelectric } & MW & 2,543 & 612 & 2,026 & 869 & 0 & 6,050 \\
\hline & & GWh & 7,824 & 2,127 & 6,037 & 2,503 & 0 & 18,491 \\
\hline & \multirow{2}{*}{ Lignite } & MW & 68 & 0 & 0 & 1200 & & 1,268 \\
\hline & & GWh & 420 & 0 & 0 & 7820,9 & & 8,241 \\
\hline & \multirow{2}{*}{ Local coal } & MW & 1,010 & 0 & 0 & 135 & & 1,145 \\
\hline & & GWh & 7,500 & 0 & 0 & 855,5 & & 8,356 \\
\hline & \multirow{2}{*}{ Natural gas } & MW & 1,413 & 154,2 & 965 & 890,4 & & 3,422 \\
\hline & & GWh & 11,247 & 1228 & 4,197 & 7,249 & 16,894 & 40,815 \\
\hline & \multirow{2}{*}{ Geothermal + wind } & MW & 538,6 & 243,4 & 1727,8 & 100 & 0 & 2,610 \\
\hline & & GWh & 2,629 & 1016,4 & 6,324 & 300 & 0 & 10,269 \\
\hline & \multirow{2}{*}{ Solar } & MW & 600 & 600 & 600 & 600 & 600 & 3,000 \\
\hline & & GWh & 1,500 & 1500 & 1,500 & 1,500 & 1,500 & 7,500 \\
\hline & \multirow{2}{*}{ Others } & MW & 307,5 & 91 & 29,2 & 0 & 0 & 428 \\
\hline & & GWh & 3,129 & 616,4 & 183,1 & 0 & 0 & 3928,7 \\
\hline \multirow{4}{*}{ 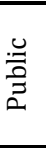 } & \multirow{2}{*}{ Hydroelectric } & MW & 64,8 & 1341,9 & 0 & 0 & 0 & 1,407 \\
\hline & & GWh & 200 & 4543 & 0 & 0 & 0 & 4,743 \\
\hline & \multirow{2}{*}{ Sum } & MW & 64,8 & 1341,9 & 0 & 0 & 0 & 1,407 \\
\hline & & GWh & 200 & 4543 & 0 & 0 & 0 & 4743 \\
\hline \multirow{6}{*}{ 岕 } & \multirow{2}{*}{ Thermal } & MW & 2,892 & 232,7 & 976 & 2225,4 & 2080 & 8,406 \\
\hline & & GWh & 22,082 & 1789 & 4,284 & 15,925 & 16,894 & 60,973 \\
\hline & \multirow{2}{*}{ Hydroelectric } & MW & 2,608 & 1954,4 & 2,027 & 869 & 0 & 7,458 \\
\hline & & GWh & 8,024 & 6,671 & 6,038 & 2,503 & 0 & 23,236 \\
\hline & \multirow{2}{*}{ Wind + renewables } & MW & 1165,2 & 855,9 & 2346 & 700 & 600 & 5,667 \\
\hline & & GWh & 4,281 & 2,572 & 7,920 & 1,800 & 1,500 & 18,073 \\
\hline & \multirow{2}{*}{ Overall sum } & MW & 6,665 & 3,043 & 5,349 & 3,795 & 2,680 & 21,531 \\
\hline & & GWh & 34,387 & 11,032 & 18,242 & 20,228 & 18,394 & 102,282 \\
\hline
\end{tabular}

\section{Analyses}

The analyses are carried out with two proposed scenarios. The Scenario 1 shows the variation of the cost of energy production in the case of current energy policies of the TEIAȘ are proceeded while the Scenario 2 emphasizes an economic appraisal of the shift from natural gas investments to hydroelectric power investments in terms of the present value of costs.

\subsection{Scenario-I}

If the current trend of energy production continues based on historical data, the electricity production figures for 2023 result.

In order to calculate the current trend in this scenario, the data is as given in Table 6 [17]. It shows the electrical energy production and consumption as a GWh between 1985 and 2014. The average yearly increase rate of electrical energy production is approximately $6 \%$. In 2013 , total share of natural gas is approximately $48 \%$, and hydropower is about $16 \%$.

Table 7 shows the projected electrical energy production from thermal, natural gas, hydropower and renewable energy sources until 2019. There is no investment in fuel oil. The planned electricity production will be made by these sources, which are either under construction or planned.

The projected electricity demand according to the "low demand" and production for various sources according to the TEİAȘ [16] is given in the second column of Table 8. By using the average yearly growth rate in electricity production between 1985 and 2014, the calculated values in this scenario are also given in Table 8. The last column shows the gross production of electricity demand since the loss of approximately $8 \%$ in production and transmission.

If this scenario (base case) continues to meet Turkey's demand for electrical energy, natural gas will reach a level of approximately $188,000 \mathrm{GWh}$ with a share of $42 \%$ and hydropower will reach $118,000 \mathrm{GWh}$ with a share of $26 \%$ (see Table 9). Similarly, renewables will reach a level of 25,000 GWh and a share of $6 \%$.

\subsection{Scenario-II}

If the projected values of the electricity production from different "energy sources" are completed until 2019 as in the TEİAŞ, keeping the natural gas electricity production fixed at that date and shifting the natural gas to hydropower through use of the new value of about 156 TWh in 2023, we achieve the electricity production figures for 2023.

The analysis in this scenario shows that after cumulatively adding the projected electricity production (see Table 7) until 2019 for each source and keeping the natural-gas power production (i.e., keeping it fixed at a value of approximately $135,000 \mathrm{GWh}$ ), while the need for electricity production is supplied by hydropower using the estimated potential of 156,000 GWh until 2023 in Section 4, the share of hydropower is obtained in Table 10.

The second and last columns of Table 10 show the projected electrical energy demand and gross electricity demand, respectively. As can be seen in Table 11, the total share of hydraulic will increase to a level of $35 \%$ and the natural gas share will reach a level of $30 \%$. The result for the 9 -year period is a realistic scenario that policy makers may apply. 
Table 6: Data for scenario analysis (TUIK).

\begin{tabular}{|c|c|c|c|c|c|c|c|}
\hline Years & $\begin{array}{l}\text { Total consumption } \\
\text { (GWh) }\end{array}$ & $\begin{array}{l}\text { Total production } \\
\text { (GWh) }\end{array}$ & $\begin{array}{c}\text { Thermal } \\
\text { (lignite + coal, \%) }\end{array}$ & $\begin{array}{l}\text { Liquid fuels } \\
(\%)\end{array}$ & $\begin{array}{c}\text { Natural gas } \\
(\%)\end{array}$ & $\begin{array}{c}\text { Hydropower } \\
(\%)\end{array}$ & $\begin{array}{l}\text { Renewable energy } \\
\text { and wastes (\%) }\end{array}$ \\
\hline 1985 & 29,709 & 34,219 & 43.9 & 20.7 & 0.2 & 35.2 & 0.0 \\
\hline 1986 & 32,210 & 39,695 & 49.0 & 17.6 & 3.4 & 29.9 & 0.1 \\
\hline 1987 & 36,697 & 44,353 & 39.8 & 12.4 & 5.7 & 42.0 & 0.1 \\
\hline 1988 & 39,722 & 48,049 & 26.0 & 6.9 & 6.7 & 60.3 & 0.1 \\
\hline 1989 & 43,120 & 52,043 & 38.9 & 8.2 & 18.3 & 34.5 & 0.1 \\
\hline 1990 & 46,820 & 57,543 & 35.1 & 6.9 & 17.7 & 40.2 & 0.1 \\
\hline 1991 & 49,283 & 60,246 & 35.8 & 5.5 & 20.9 & 37.7 & 0.2 \\
\hline 1992 & 53,985 & 67,342 & 36.5 & 7.8 & 16.1 & 39.5 & 0.2 \\
\hline 1993 & 59,237 & 73,808 & 32.2 & 7.0 & 14.6 & 46.0 & 0.2 \\
\hline 1994 & 61,401 & 78,322 & 36.0 & 7.1 & 17.6 & 39.1 & 0.2 \\
\hline 1995 & 67,394 & 86,247 & 32.5 & 6.7 & 19.2 & 41.2 & 0.4 \\
\hline 1996 & 74,157 & 94,862 & 32.1 & 6.9 & 18.1 & 42.7 & 0.3 \\
\hline 1997 & 81,885 & 103,296 & 32.8 & 6.9 & 21.4 & 38.5 & 0.4 \\
\hline 1998 & 87,705 & 111,022 & 32.1 & 7.1 & 22.4 & 38.0 & 0.3 \\
\hline 1999 & 91,202 & 116,440 & 31.8 & 6.9 & 31.2 & 29.8 & 0.3 \\
\hline 2000 & 98,296 & 124,922 & 30.6 & 7.5 & 37.0 & 24.7 & 0.3 \\
\hline 2001 & 97,070 & 122,725 & 31.3 & 8.4 & 40.4 & 19.6 & 0.3 \\
\hline 2002 & 102,948 & 129,400 & 24.8 & 8.3 & 40.6 & 26.0 & 0.3 \\
\hline 2003 & 111,766 & 140,581 & 22.9 & 6.5 & 45.2 & 25.1 & 0.2 \\
\hline 2004 & 121,142 & 150,698 & 22.9 & 5.1 & 41.3 & 30.6 & 0.2 \\
\hline 2005 & 130,263 & 161,956 & 26.7 & 3.4 & 45.3 & 24.4 & 0.2 \\
\hline 2006 & 143,070 & 176,300 & 26.5 & 2.5 & 45.8 & 25.1 & 0.2 \\
\hline 2007 & 155,135 & 191,558 & 27.9 & 3.4 & 49.6 & 18.7 & 0.4 \\
\hline 2008 & 161,948 & 198,418 & 29.1 & 3.8 & 49.7 & 16.8 & 0.6 \\
\hline 2009 & 156,894 & 194,813 & 28.6 & 2.5 & 49.3 & 18.5 & 1.2 \\
\hline 2010 & 172,051 & 211,208 & 26.1 & 1.0 & 46.5 & 24.5 & 1.9 \\
\hline 2011 & 186,100 & 229,395 & 28.9 & 0.4 & 45.4 & 22.8 & 2.6 \\
\hline 2012 & 194,923 & 239,497 & 28.4 & 0.7 & 43.6 & 24.2 & 3.1 \\
\hline 2013 & 198,045 & 240,154 & 26.6 & 0.7 & 43.8 & 24.7 & 4.2 \\
\hline 2014 & 207,375 & 251,963 & 30.3 & 0.9 & 47.9 & 16.1 & 4.9 \\
\hline
\end{tabular}

Table 7: Projected electric energy production from various sources until 2019 (TEİAȘ).

\begin{tabular}{ccccc}
\hline Years & $\begin{array}{c}\text { Thermal } \\
\text { (Lignite + Coal, GWh) }\end{array}$ & $\begin{array}{c}\text { Fuel Oil } \\
\text { (GWh) }\end{array}$ & $\begin{array}{c}\text { Natural Gas } \\
\text { (GWh) }\end{array}$ & $\begin{array}{c}\text { Hydropower } \\
\text { (GWh) }\end{array}$ \\
\hline 2015 & 7,920 & 884.1 & 11,247 & 7,824 \\
2016 & 0 & 474.1 & 1,228 & 2,127 \\
2017 & 0 & 0 & 4,197 & 6,037 \\
2018 & 8,676 & 0 & 7,249 & 2,516 \\
2019 & 0 & 0 & 16,894 & 1,824 \\
\hline
\end{tabular}

Table 8: Current trend scenario and average growth rate of electricity production.

\begin{tabular}{|c|c|c|c|c|c|c|}
\hline Years & $\begin{array}{c}\text { TEIAS } \\
\text { projection for } \\
\text { "low demand" (GWh) }\end{array}$ & $\begin{array}{l}\text { Thermal (lignite }+ \\
\text { coal) (GWh) }\end{array}$ & $\begin{array}{l}\text { Natural gas } \\
\quad(\text { GWh) }\end{array}$ & $\begin{array}{l}\text { Hydropower } \\
\text { (GWh) }\end{array}$ & $\begin{array}{c}\text { Renewable } \\
\text { (wind+geothermal+ } \\
\text { etc.) (GWh) }\end{array}$ & $\begin{array}{c}\text { Gross production } \\
\text { (GWh) }\end{array}$ \\
\hline 2015 & 271,450 & 81,648 & 120,743 & 72,556 & 13,376 & 288,324 \\
\hline 2016 & 287,310 & 84,648 & 131,020 & 81,332 & 16,347 & 313,348 \\
\hline 2017 & 302,750 & 85,298 & 135,217 & 84,642 & 17,905 & 323,063 \\
\hline 2018 & 319,980 & 90,160 & 142,925 & 89,467 & 18,926 & 341,478 \\
\hline 2019 & 338,270 & 95,299 & 151,072 & 94,566 & 20,005 & 360,942 \\
\hline 2020 & 357,430 & 100,731 & 159,683 & 99,957 & 21,145 & 381,515 \\
\hline 2021 & 376,150 & 106,473 & 168,785 & 105,654 & 22,350 & 403,262 \\
\hline 2023 & 415,680 & 118,957 & 188,574 & 118,042 & 24,971 & 450,544 \\
\hline
\end{tabular}

Table 9: Total share of electricity production in Scenario I.

\begin{tabular}{ccccc}
\hline Years & Thermal (lignite + coal) (\%) & Natural gas (\%) & Hydropower (\%) & Renewable (wind+geothermal+etc.) (\%) \\
\hline 2015 & 28 & 42 & 25 & 26 \\
2016 & 27 & 42 & 26 & 26 \\
2017 & 26 & 42 & 26 & 5 \\
2018 & 26 & 41 & 26 & 5 \\
2019 & 26 & 41 & 26 & 5 \\
2020 & 26 & 41 & 26 & 6 \\
2021 & 26 & 42 & 26 & 6 \\
2022 & 26 & 42 & 42 & 6 \\
2023 & 26 & 42 & \\
\hline
\end{tabular}


Table 10: Application of Scenario II.

\begin{tabular}{|c|c|c|c|c|c|c|}
\hline Years & $\begin{array}{l}\text { TEİAŞ projection } \\
\text { for } \\
\text { "low demand" } \\
\text { (GWh) }\end{array}$ & $\begin{array}{l}\text { Thermal (lignite }+ \\
\text { coal) (GWh) }\end{array}$ & $\begin{array}{l}\text { Natural gas } \\
\text { (GWh) }\end{array}$ & $\begin{array}{l}\text { Hydropower } \\
\text { (GWh) }\end{array}$ & $\begin{array}{c}\text { Renewable } \\
\text { (wind+geothermal+ } \\
\text { etc.) (GWh) }\end{array}$ & $\begin{array}{c}\text { Gross production } \\
\text { (GWh) }\end{array}$ \\
\hline 2015 & 271,450 & 81,648 & 120,743 & 72,556 & 13,376 & 288,324 \\
\hline 2016 & 287,310 & 84,648 & 131,020 & 81,332 & 16,347 & 313,348 \\
\hline 2017 & 302,750 & 85,298 & 135,217 & 84,642 & 17,905 & 323,063 \\
\hline 2018 & 319,980 & 93,865 & 135,217 & 96,442 & 20,054 & 345,578 \\
\hline 2019 & 338,270 & 99,411 & 135,217 & 108,242 & 22,461 & 365,332 \\
\hline 2020 & 357,430 & 105,609 & 135,217 & 120,042 & 25,156 & 386,024 \\
\hline 2022 & 395,540 & 116,768 & 135,217 & 143,642 & 31,556 & 427,183 \\
\hline 2023 & 415,680 & 122,933 & 135,217 & 155,442 & 35,342 & 448,934 \\
\hline
\end{tabular}

Table 11: Total share of electricity production in Scenario II.

\begin{tabular}{ccccc}
\hline Years & Thermal (lignite + coal) (\%) & Natural gas (\%) & Hydropower (\%) & Renewable (wind+geothermal+etc.) (\%) \\
\hline 2015 & 28 & 42 & 25 & 26 \\
2016 & 27 & 42 & 26 & 5 \\
2017 & 26 & 42 & 28 \\
2018 & 27 & 39 & 30 & 6 \\
2019 & 27 & 37 & 31 & 6 \\
2020 & 27 & 35 & 32 & 7 \\
2021 & 27 & 33 & 34 & 7 \\
2022 & 27 & 32 & 35 & 8 \\
2023 & 27 & 30 & & \\
\hline
\end{tabular}

Figure 5 compares the total share of electricity production from natural gas and hydropower plants. It includes the possible application of a scenario that would change the total share of electricity production from $26 \%$ to $35 \%$ until 2023 . Similarly, the natural-gas power production will decrease from a share of $42 \%$ to $30 \%$ by 2023 . Next section compares the economic analysis of two scenarios in terms of Net Present value (NPD) in a 30-year time span.

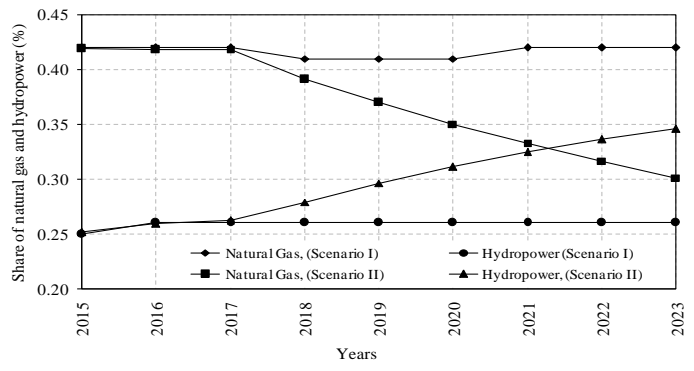

Figure 5: Comparison of scenarios.

\section{Financial calculations for proposed scenario}

\subsection{Initial investment cost}

The initial investment costs of power plants for energy production vary according to the performance of the machinery, topography, geology, manpower, land prices, etc. Thus the initial investment costs of energy plants can be calculated as per the local conditions of the country. The management and control duties of energy market in Turkey belong to the Energy Market Regulatory Authority (EPDK). This institution has calculated the unit investment costs as given in Table 12, based on the average values of several power plants [20].

As can be seen in Table 12, one of the cheapest initial costs in Turkey is the natural gas cycle power plant and the most expensive is the wind power plant. Similarly, operation costs vary in terms of manpower wages, fuel prices and other parity factors in the country. A significant number of energy power plants are operated by corporations for the Electricity
Generation Company (EÜAŞ). According to data in consideration of the end of 2013 reproduced by the EÜAŞ, operation costs of natural gas, thermal, renewable energy power plants and hydroelectric power plants have been calculated, providing the results shown in Table 13.

Table 12: Investment costs of power plants (EPDK).

\begin{tabular}{cc}
\hline Sources & Investment cost (USD/MWe) \\
\hline Coal & 705,000 \\
Natural gas & 470,000 \\
Fuel oil & 470,000 \\
Hydroelectric & 950,000 \\
Wind & $1,175,000$ \\
Geothermal & $1,000,000$ \\
Biomass & 900,000 \\
Solar & $1,400,000$ \\
\hline
\end{tabular}

Table 13: Operation and maintenance costs of power plants [21].

\begin{tabular}{ccccc}
\hline & $\begin{array}{c}\text { Hydropower } \\
(\$ / \mathrm{kWh})\end{array}$ & $\begin{array}{c}\text { Natural gas } \\
(\$ / \mathrm{kWh})\end{array}$ & \multicolumn{2}{c}{ Thermal } \\
$(\$ / \mathrm{kWh})$ & $\begin{array}{c}\text { Renewable } \\
(\$ / \mathrm{kWh})\end{array}$ \\
\hline Resource & 0 & 0.1092 & 0.0419 & 0 \\
Material & 0.0001 & 0.0003 & 0.0016 & 0.0001 \\
$\begin{array}{c}\text { Industrial payment } \\
\text { Employment } \\
\text { payment }\end{array}$ & 0.0012 & 0.0008 & 0.006 & 0.0012 \\
$\begin{array}{c}\text { Outsourced service } \\
\text { fee }\end{array}$ & 0.0006 & 0.0003 & 0.0008 & 0.0006 \\
$\begin{array}{c}\text { Other expenses } \\
\text { Taxes }\end{array}$ & 0.00031 & 0.002 & 0.0076 & 0.0041 \\
Amortization & 0 & 0.0002 & 0.001 & 0.0003 \\
Sum & 0.0019 & 0.0008 & 0.0004 & 0 \\
\hline
\end{tabular}

As can be seen in Table 13, the operation cost of a hydroelectric power plant is $0.0082(\$ .082)$ for each $\mathrm{kWh}$ of energy, while this expenditure is 0.1137 ( $\$ 11.37$ ) in a natural-gas burning facility. The thermal power plant operating cost is $\$ 0.07$ and the renewable is approximately $\$ .082$, which is similar to hydropower.

\subsection{Economic evaluations by present value}

The definition of "Net Present Value (NPV)" is that the difference between the present value of cash inflow and the 
present value of cash outflow. NPV is used in capital budgeting to analyze the profitability of an investment or project. Equation 1 is used to calculate the NPV:

$$
N P V=\sum_{j=1}^{n} \frac{c_{j}}{(1+i)^{j}}-c_{0}
$$

Where, $c_{j}$ represents net cash inflow during the period, $c_{o}$ is the initial investment; $i$ is the discount rate, while $n$ is the number of time periods. Within the scope of this study, the Present Value (PV) has been used instead of the NPV. The relevant formula for calculation of the present value is given below:

$$
P V=\frac{c}{(1+i)^{n}}
$$

where $c$ is the future amount of money that must be discounted, $\mathrm{n}$ is the number of the compounding period between the present date and the date where the sum is worth $c$, and $i$ is the interest rate for one compounding period (the end of a compounding period is when interest is applied). The initial investment and operation costs which will be used for calculating PVs of scenarios are given in Table 14.

Table 14: Capacity factor and unit costs of power plants (EPDK).

\begin{tabular}{lccc}
\hline Plant Type & $\begin{array}{c}\text { Capacity factor } \\
(\%)\end{array}$ & $\begin{array}{c}\text { Investment Cost } \\
\left(10^{6} \$\right)\end{array}$ & $\begin{array}{c}\text { Unit Cost } \\
(\$)\end{array}$ \\
\hline Natural gas & 87 & 0.470 & 0.1137 \\
Hydropower & 53 & 0.950 & 0.0082 \\
Thermal & 87 & 0.705 & 0.0707 \\
Renewable & 60 & 1.100 & 0.0082 \\
\hline
\end{tabular}

Table 15 shows the PV calculation of Scenario I until 2023. The cumulative present value of Scenario I is approximately $\$ 35$ billion in 2023. The PV of Scenario II is given in Table 16 until 2023. With this scenario, the PV is approximately $\$ 30.5$ billion in 2023 with a savings of approximately $13 \%$.

Figure 6 shows the total cumulative present values of scenarios until 2043 with a social discount rate of $9 \%$. The reason for using the 28-year time span from now on is that the initial investment cost will compensate within about 10 years, after which only the costs of operation and maintenance will be available.

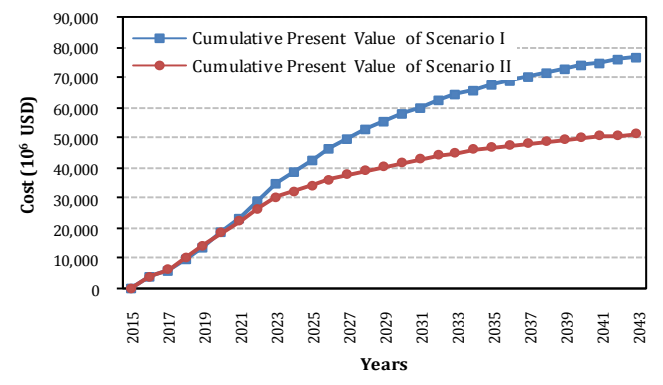

Figure 6: Cumulative present value comparison.

Within a 28-year time span, the cumulative present value of Scenario I is approximately $\$ 77$ billion and the Scenario II is approximately $\$ 52$ billion with a saving of $\$ 25$ billion or a saving of approximately $32 \%$ when compared with Scenario I.

\section{Conclusions}

This study investigates the possible hydropower potential of Turkey and proposes two scenarios. The electrical energy demand in Turkey is also utilized. The economically feasible hydropower potential is investigated in the literature and the DSI plans. Two scenarios are developed using the historical data and the new value of hydroelectric potential. The following findings may be drawn from this study:

\begin{tabular}{|c|c|c|c|c|c|c|c|c|c|c|c|}
\hline \multirow{2}{*}{ Source } & & \multirow{2}{*}{ Unit } & \multicolumn{9}{|c|}{ Years } \\
\hline & & & 2015 & 2016 & 2017 & 2018 & 2019 & 2020 & 2021 & 2022 & 2023 \\
\hline \multirow{5}{*}{ 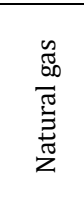 } & Capacity & MW & 30 & 1,220 & 545 & 1,011 & 1,069 & 1,130 & 1,194 & 1,262 & 1,334 \\
\hline & Investment cost & $10^{6}$ USD & 14 & 573 & 256 & 475 & 502 & 531 & 561 & 593 & 627 \\
\hline & Cumulative production & GWh & 26 & 10,303 & 14,500 & 22,208 & 30,355 & 38,966 & 48,068 & 57,688 & 67,857 \\
\hline & Cumulative operational and maintenance cost & $\$, 10^{6}$ & 3 & 1,171 & 1,649 & 2,525 & 3,451 & 4,430 & 5,465 & 6,559 & 7,715 \\
\hline & Total cost & $\$, 10^{6}$ & 17 & 1,745 & 1,905 & 3,000 & 3,954 & 4,961 & 6,027 & 7,152 & 8,342 \\
\hline \multirow{6}{*}{ 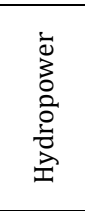 } & Capa & MW & 305 & 1,890 & 713 & 1,039 & 1,098 & 1,161 & 1,227 & 1,297 & 1.371 \\
\hline & Installation & $10^{6}$ USD & 289 & 1,796 & 677 & 987 & 1,043 & 1,103 & 1,166 & 1,232 & 1.303 \\
\hline & Electricity & GWh & 1,414 & 8,776 & 3,310 & 4,825 & 5,099 & 5,391 & 5,697 & 6,022 & 6.366 \\
\hline & Cumulative Production & GWh & 1,414 & 10,190 & 13,500 & 18,325 & 23,424 & 28,815 & 34,512 & 40,534 & 46.900 \\
\hline & Cumulative operational an & $\$, 10^{6}$ & 12 & 84 & 111 & 150 & 192 & 236 & 283 & 332 & 385 \\
\hline & Tota & $\$, 10^{6}$ & 301 & 1,879 & 788 & 1,138 & 1,235 & 1,339 & 1,449 & 1,565 & 1.687 \\
\hline \multirow{5}{*}{ 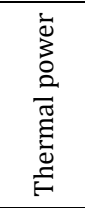 } & Cap & MW & 0 & 394 & 85 & 638 & 674 & 713 & 753 & 796 & 842 \\
\hline & Inst & $10^{6}$ USD & 0 & 278 & 60 & 450 & 475 & 502 & 531 & 561 & 593 \\
\hline & Electrici & GWh & 0 & 3,000 & 650 & 4,862 & 5,139 & 5,432 & 5,742 & 6,069 & 6.415 \\
\hline & Cumulative operational and & $\$, 10^{6}$ & 0 & 212 & 258 & 602 & 965 & 1,349 & 1,755 & 2,184 & 2.638 \\
\hline & Total cost & $\$, 10^{6}$ & 0 & 490 & 318 & 1,052 & 1,441 & 1,852 & 2,286 & 2,746 & 3.231 \\
\hline \multirow{9}{*}{ 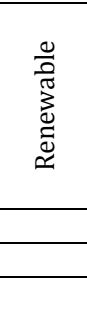 } & Cap & MW & 130 & 565 & 296 & 194 & 205 & 217 & 229 & 242 & 256 \\
\hline & Inst & $\$, 10^{6}$ & 143 & 622 & 326 & 214 & 226 & 239 & 252 & 267 & 282 \\
\hline & duction & GWh & 683 & 2,971 & 1,558 & 1,021 & 1,079 & 1,140 & 1,205 & 1,274 & 1.347 \\
\hline & Cumulative production & GWh & 683 & 3,654 & 5,212 & 6,233 & 7,312 & 8,452 & 9,657 & 10,931 & 12.278 \\
\hline & Cumulative operational and maintenance cost & $\$, 10^{6}$ & 6 & 30 & 43 & 51 & 60 & 69 & 79 & 90 & 101 \\
\hline & Total cost & $\$, 10^{6}$ & 149 & 652 & 369 & 265 & 286 & 308 & 331 & 356 & 383 \\
\hline & all sources & $\$, 10^{6}$ & 467 & 4,765 & 3,380 & 5,454 & 6,915 & 8,460 & 10,093 & 11,819 & 13,643 \\
\hline & & $\$, 10^{6}$ & 393 & 3,680 & 2,394 & 3,545 & 4,123 & 4,628 & 5,065 & 5,442 & 5,763 \\
\hline & Cumulative present value of Scenario I & $\$, 10^{6}$ & 393 & 4,073 & 6,467 & 10,012 & 14,135 & 18,763 & 23,829 & 29,270 & 35,034 \\
\hline
\end{tabular}

Table 15: PV analysis of Scenario I. 
Table 16: PV analysis of Scenario II.

\begin{tabular}{|c|c|c|c|c|c|c|c|c|c|c|c|}
\hline \multirow[b]{2}{*}{ Source } & & \multirow{2}{*}{ Unit } & \multicolumn{9}{|c|}{ Years } \\
\hline & & & 2015 & 2016 & 2017 & 2018 & 2019 & 2020 & 2021 & 2022 & 2023 \\
\hline \multirow{6}{*}{ 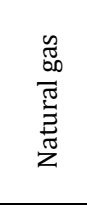 } & Capacity & MW & 30 & 1,220 & 545 & 0 & 0 & 0 & 0 & 0 & 0 \\
\hline & Investment cost & $10^{6}$ USD & 14 & 573 & 256 & 0 & 0 & 0 & 0 & 0 & 0 \\
\hline & Electricity production & GWh & 26 & 10,277 & 4,197 & 0 & 0 & 0 & 0 & 0 & 0 \\
\hline & Cumulative production & GWh & 26 & 10,303 & 14,500 & 14,500 & 14,500 & 14,500 & 14,500 & 14,500 & 14.500 \\
\hline & Cumulative operational and maintenance cost & $\$, 10^{6}$ & 3 & 1,171 & 1,649 & 1,649 & 1,649 & 1,649 & 1,649 & 1,649 & 1.649 \\
\hline & Total cost & $\$, 10^{6}$ & 17 & 1,745 & 1,905 & 1,649 & 1,649 & 1,649 & 1,649 & 1,649 & 1.649 \\
\hline \multirow{6}{*}{ 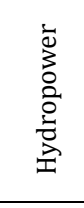 } & Capacity & MW & 305 & 1,890 & 713 & 2,542 & 2,542 & 2,542 & 2,542 & 2,542 & 2.542 \\
\hline & Installation cost & $10^{6}$ USD & 289 & 1,796 & 677 & 2,415 & 2,415 & 2,415 & 2,415 & 2,415 & 2.415 \\
\hline & Electricity production & GWh & 1,414 & 8,776 & 3,310 & 11,800 & 11,800 & 11,800 & 11,800 & 11,800 & 11.800 \\
\hline & Cumulative Production & GWh & 1,414 & 10,190 & 13,500 & 25,300 & 37,100 & 48,900 & 60,700 & 72,500 & 84.300 \\
\hline & Cumulative operational and maintenance cost & $\$, 10^{6}$ & 12 & 84 & 111 & 207 & 304 & 401 & 498 & 595 & 691 \\
\hline & Total cost & $\$ .10^{6}$ & 301 & 1,879 & 788 & 2,622 & 2,719 & 2,816 & 2,913 & 3,009 & 3.106 \\
\hline \multirow{6}{*}{ 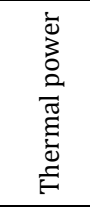 } & Capacity & MW & 0 & 394 & 85 & 1,124 & 728 & 813 & 708 & 756 & 809 \\
\hline & Installation cost & $10^{6}$ USD & 0 & 278 & 60 & 792 & 513 & 573 & 499 & 533 & 570 \\
\hline & Electricity production & GWh & 0 & 3,000 & 650 & 8,567 & 5,546 & 6,198 & 5,399 & 5,760 & 6.165 \\
\hline & Cumulative production & GWh & 0 & 3,000 & 3,650 & 12,217 & 17,763 & 23,961 & 29,360 & 35,120 & 41.285 \\
\hline & Cumulative operational and maintenance cost & $\$, 10^{6}$ & 0 & 212 & 258 & 864 & 1,256 & 1,694 & 2,076 & 2,483 & 2.919 \\
\hline & Total cost & $\$, 10^{6}$ & 0 & 490 & 318 & 1,656 & 1,769 & 2,267 & 2,575 & 3,016 & 3.489 \\
\hline \multirow{9}{*}{$\begin{array}{l}\frac{0}{0} \\
\frac{\pi}{\pi} \\
3 \\
0 \\
0 \\
\approx\end{array}$} & Capacity & MW & 130 & 565 & 296 & 409 & 458 & 513 & 574 & 643 & 720 \\
\hline & Installation cost & $10^{6}$ USD & 143 & 622 & 326 & 450 & 504 & 564 & 632 & 708 & 792 \\
\hline & Electricity production & GWh & 683 & 2,971 & 1,558 & 2,149 & 2,407 & 2,695 & 3,019 & 3,381 & 3.786 \\
\hline & Cumulative production & GWh & 683 & 3,654 & 5,212 & 7,361 & 9,768 & 12,463 & 15,482 & 18,863 & 22.649 \\
\hline & Cumulative operational and maintenance cost & $\$, 10^{6}$ & 6 & 30 & 43 & 60 & 80 & 102 & 127 & 155 & 186 \\
\hline & Total cost & $\$, 10^{6}$ & 149 & 652 & 369 & 510 & 584 & 666 & 759 & 862 & 978 \\
\hline & Total cost of all sources & $\$, 10^{6}$ & 467 & 4,765 & 3,380 & 6,437 & 6,720 & 7,398 & 7,895 & 8,536 & 9,222 \\
\hline & Scenario II & $\$, 10^{6}$ & 393 & 3,680 & 2,394 & 4,184 & 4,007 & 4,047 & 3,962 & 3,930 & 3,895 \\
\hline & Cumulative present value of Scenario II & $\$, 10^{6}$ & 393 & 4,073 & 6,467 & 10,651 & 14,658 & 18,705 & 22,667 & 26,598 & 30,493 \\
\hline
\end{tabular}

A review of the literature showed that the economically feasible hydroelectric potential ranges from 125 to $140 \mathrm{TWh}$. This study found that the value will reach a level of $156 \mathrm{TWh}$, taking into account the hydropower planned and under construction, including Small Hydroelectric Power Plants (SHPs).

The total share of electricity production from hydropower will increase from $26 \%$ to $35 \%$ when compared with Scenario I. Similarly, natural-gas power production will decrease from $42 \%$ to $30 \%$ in 2023 .

Economic analysis showed that if Scenario II is applied, the cumulative present value of gain is approximately 32\% in 2043 . In other words, the Scenario 2 will save approximately 28,000*106 USD in comparison to Scenario 1 in 2043.

Nuclear energy has not been investigated in this study since the first nuclear power started to construct nowadays and it is expected that the production of energy will start in 2023 as a full capacity [22]. Thus the policies and scenario in this study has not been affected until 2023. Subsequently, the nuclear energy needs to be taken into account for energy balance.

Future studies should focus on investigating the potential roles of other renewables and should concentrate on increasing the share of renewables in the overall production of electrical energy.

\section{Reference}

[1] Hepbasli A, Ozgener 0. "Turkey's renewable energy sources: Part 1. historical development". Energy Sources, 26(10), 961-969, 2004.

[2] Ozgener 0. "A review of blade structures of swtss in the aegean region and performance analysis". Renewable and Sustainable Energy Reviews, 9(1), 85-99, 2005.
[3] Akdeniz RC, Acaroglu M, Hepbasli A. "Cotton stalk as a potential energy source". Energy Sources, 26(1), 65-75, 2004.

[4] Erdogdu E. "An analysis of turkish hydropower policy". Renewable and Sustainable Energy Reviews, 15(1), 689-696. 2011.

[5] Toklu E, Güney MS, Isık M, Comaklı O, Kaygusuz K. "Energy production, consumption, policies and recent developments in Turkey". Renewable and Sustainable Energy Reviews, 14(4), 1172-1186, 2010.

[6] Capik M, Yılmaz A0, Cavusoglu I. "Hydropower for sustainable energy development in turkey: the small hydropower case of the eastern black sea region". Renewable and Sustainable Energy Reviews, 16(8), 6160-6172, 2012.

[7] Bakir NN. “Turkey's Hydropower Potential and Review of Electricity Generation Policies from EU Perspective". http://www.ere.com.tr/pdf/HYDRO_POL_PREZ_EN.pdf (15.01.2016).

[8] Yuksek 0, Kaygusuz K. "Small hydropower plants as a renewable energy source". Energy Sources, 1(3), 279-290, 2006.

[9] Kaygusuz K. "Renewable and sustainable energy use in turkey: A review". Renewable and Sustainable Energy Reviews, 6(4), 339-366, 2002.

[10] Yuksek O, Komurcu MI, Yuksel I, Kaygusuz K. "The role of hydropower in meeting turkey's electric energy demand". Energy Policy, 34(17), 3093-3103, 2006.

[11] Devlet Su İșleri. "Devlet Su İșleri Genel Müdürlüğü". http://www.dsi.gov.tr/faaliyetler/hessu-kullanimanlasmalari (16.01.2015).

[12] Berkun M. "Hydroelectric potential and environmental effects of multidam hydropower projects in Turkey". Energy for Sustainable Development, 14(4), 320-329,2010. 
[13] Dursun B, Gokcol C. "The role of hydroelectric power and contribution of small hydropower plants for sustainable development in Turkey". Renewable Energy, 36(4), 1227-1235, 2011.

[14] Yuksel I. "Renewable energy status of electricity generation and future prospect hydropower in Turkey". Renewable Energy, 50, 1037-1043, 2013.

[15] Yüksek Ö. "Reevaluation of Turkey's hydropower potential and electric energy demand". Energy Policy, 3 (9),3374-3382, 2008.

[16] Turkish Electricity Transmission Company. "Turkey Electricity Energy 5-Year Generation Capacity Projection 2015-2019"

http://www.teias.gov.tr/YayinRapor/APK/projeksiyon/ KAPASITEPROJEKSIYONU2015.pdf (08.02.2016).

[17] Turkish Statistical Institute. "Electricity Generation and Shares by Energy Resources". http://www.tuik.gov.tr/PreIstatistikTablo.do?istab_id=1 $578(08.02 .2016)$
[18] Electricity Generation Company. "Electricity Generation Sector Report" http://www.enerji.gov.tr/File/?path=R00T\%2F1\%2FDo cuments\%2FSekt\%C3\%B6r+Raporu\%2FSektor_Raporu_ EUAS_2011.pdf (08.02.2016).

[19] Melikoglu M. "Hydropower in Turkey: Analysis in the view of vision 2023". Renewable and Sustainable Energy Reviews, 25, 503-510,2013.

[20] Energy Market Regulatory Authority. "Total Unit Investment Amounts by Source". http://www3.epdk.org.tr/index.php/epdkyayinrapor/elektrik-dogalgaz-verileri/11-icerik/819epd-kaynakbazindabirimyatirim(08.02.2016).

[21] Turkish Court of Accounts. "Accountability Report 2013". http://www.sayistay.gov.tr/rapor/kit/2013/17E\%C3\%9CA\%C5\%9E\%202013.pdf (08.02.2016).

[22] Akkuyu Electricity Generation. "Akkuyu Nükleer". http://www.akkunpp.com/index.php (08.02.2016). 